\title{
PRELIMINARY CHARACTERISATION OF BACILLUS SUBTILIS STRAIN USE AS A DIETARY PROBIOTIC BIO-ADDITIVE IN WEANING PIGLET
}

\author{
Mihaela Dumitru ${ }^{* 1,2}$, Ionuț Sorescu ${ }^{1}$, Mihaela Habeanu ${ }^{1}$, Cristina Tabuc ${ }^{1}$, Lavinia Idriceanu ${ }^{1}$, \\ Stefana Jurcoane ${ }^{2,3}$ \\ ${ }^{1}$ National Research Development Institute for Biology and Animal Nutrition (IBNA), Bucharest, No. 1, \\ Balotesti, Ilfov, 077015, Romania \\ ${ }^{2}$ University of Agronomic Sciences and Veterinary Medicine of Bucharest, 59, Marasti Blvd, District 1, \\ Bucharest, Romania \\ ${ }^{3}$ Academy of Romanian Scientists, Bucharest, Romania
}

"Corresponding author:

E-mail address: mihaela.dumitru22@yahoo.com

\begin{abstract}
The aim of the study was to characterize the Bacillus subtilis ATCC 6051a strain, in order to establish its probiotic utility in piglet nutrition. The strain was assayed morphologically, culturally, biochemically, for hemolytic activity and enzymatically (amylase and protease). The identification and analysis of the biochemical characteristics was performed by catalase assay, API 50 CHB Biomerieux strips, apiweb API 50 CHB V 4.0 soft (B. subtilis very good identification, 99.4\% ID) and ABIS online. The hemolytic activity was assayed on blood agar medium. The growth activity of strain was evaluated in two ways: static incubation $\left(30{ }^{\circ} \mathrm{C}, 24 \mathrm{~h}, 1.36 \times 10^{8} \mathrm{CFU} / \mathrm{ml}\right)$ and under constant agitation $\left(30^{\circ} \mathrm{C}, 24 \mathrm{~h}, 150 \mathrm{rpm},\left(1.6 \times 10^{9} \mathrm{CFU} / \mathrm{ml}\right)\right.$. The strain is a Gram - positive and rodshaped bacteria, arranged in short chains or in small irregular pairs with ability to produce spores on nutrient medium. The endospores were central, paracentral and subterminal, which did not deform the vegetative cell. The strain growth was aerobic and was non - hemolytic. The enzymatic process was observed by appearance of distinct zones around strain colonies. In conclusion, the results suggested that the strain present probiotic traits and can be further assessed for other probiotic characters (resistance to $\mathrm{pH} 2.0$, resistance to bile acids and salts, antibacterial activity, induction of local immune response etc.).
\end{abstract}

Key words: API $50 \mathrm{CHB}$, hemolytic activity, enzymatic screening

\section{INTRODUCTION}

The Bacillus species constitutes an interesting group of probiotic bacteria for humans (Ritter et al., 2018) and animals as direct fed microbials (DFM) (Lese et al., 2007). DFM or probiotics are defined as life microorganisms which, when administered in adequate amounts, confer a health benefit on the host (FAO/WHO, 2001).

Microorganisms used in animal feed as probiotic products may contain one or more bacterial strains. In the European Union (EU) microorganisms added as feed supplementation are bacterial strains, often Gram-positive belonging to the following genus: Bacillus ( $B$. cereus var. toyoi, $B$. licheniformis, B. subtilis), Enterococcus (E. faecium), Lactobacillus (L. acidophilus, $L$. casei, L. farciminis, L. plantarum, L. rhamnosus), Pediococcus (P. acidilactici), Streptococcus (S. infantarius); some others probiotics are microscopic fungi such as 
strains of yeast belonging to the Saccharomyces cerevisiae species and Kluyveromyces (Markowiak and Śliżewska, 2018; Yang et al., 2015a; Bajagai et al., 2016).

The most important sources for enzyme production are microorganisms. Selection of the right organism plays a key role in high yield of enzymes (Vishwanatha et al., 2010). Supplementation with probiotic as bioadditive in animal livestock suggested the most desirable alternative for intestinal microbiota by increased intestinal immunity, improved resistance to disease, reduced number of pathogens bacteria and improved animal health (Markowiak and Śliżewska, 2018; Meng et al., 2010; Yirga, 2015).

Probiotic used in piglets feed based on Bacillus subtilis (B. subtilis) improved parameters such as: weight gains, feed conversion, meat quality (Link and Kovac, 2006), animal health by modifying microbiota and pig's performance (Kaewtapee et al., 2017). These microorganisms have demonstrated high probiotic potential; they have the ability of sporulation, thereby making them stable during thermal treatment of feed (high temperature and pressure), resistance during the enzymatic digestion along to the gastrointestinal tract (Cutting, 2011). B. subtilis is a strain which grows efficiently with low-cost carbon and nitrogen sources. Their enzymatic capacity is very efficient breaking down a great variety of proteins, carbohydrates and lipids from animal and vegetable origin, into their constituent units (Zaid, 2018).

The objective of this study, was to assess the $B$. subtilis ATCC 6051a strain, to describe morphological, cultural, and biochemical characteristics, hemolytic ability and enzymatic production (amylase and protease screening), as a preliminary investigation of probiotic potential in order to use it in piglet nutrition.

\section{MATERIAL AND METHODS}

\section{Characterization of bacterial strain, growth media and enumeration of spore counts}

Morphological and cultural properties of $B$. subtilis ATCC 6051a strain was investigated according to the methods described in Bergey's Manual of Systematic Bacteriology
(1957). Bacteria B. subtilis ATCC 6051a was grown in nutrient broth (Merck) and on nutrient agar (Merck), $90 \mathrm{~mm}$ in Petri dishes, to evaluate the cultural traits. Serial dilution $(1: 10$, in $0.85 \%$ saline) was done $\left(10^{-5}-10^{-10}\right.$-fold), for CFU/ml in broth culture, incubated static $\left(30{ }^{\circ} \mathrm{C}, 24-48 \mathrm{~h}\right)$ and under agitation $\left(30^{\circ} \mathrm{C}, 24 \mathrm{~h}, 150 \mathrm{rpm}\right)$. An aliquot of $1 \mathrm{ml}$ from each dilution was homogenized and spread on nutrient agar plate. At least three replicas were done for each dilution. The strain was stored at $80^{\circ} \mathrm{C}$ with $20 \%$ sterile glycerol and deposited in the Collection of National Research Development Institute for Biology and Animal Nutrition Balotesti (INCDBNA), Romania, under the code IBNA 74. The research was carried out at Laboratory of Biotechnology of (INCDBNA), Romania.

\section{Biochemical test}

The strain was tested for biochemical characters (catalase assay, API $50 \mathrm{CHB}$ Biomerieux strips) and identified by API 50 CHB V4.0 and ABIS online soft.

\section{The catalase test}

Analysis of catalase test was done according to the protocol described by Dumitru et al. (2017).

\section{The API 50 CHB test}

API $50 \mathrm{CHB}$ strips were used for evaluated the carbohydrate acidification of $B$. subtilis ATCC 6051a according to the manufacturer's protocol (BioMerieux). The API 50 $\mathrm{CHB}$ consists of 50 microtubes used to study fermentation of substrates belonging to the carbohydrate family and its derivatives. The density of the suspensions used for API test was adjusted to 2.0 McFarland standard turbidity. The strips are read after $24 \mathrm{~h}$ incubation, with a final interpretation after $48 \mathrm{~h}$, at $37^{\circ} \mathrm{C}$, in aerobic conditions. The obtained results are interpreted using database system API $50 \mathrm{CHB}$ V4.0 and ABIS online software (Stoica and Sorescu, 2017).

\section{Hemolysis production}

Blood agar plates [Trypticase soy agar (TSA, Sanimed) containing 5\% (w/v)] sheep blood, were used to test hemolysis activity. The strain was streaked on blood agar plates and incubated at $37{ }^{\circ} \mathrm{C}$, for $24 \mathrm{~h}$. In 
this test, a greenish zone around bacteria indicates $\alpha$-hemolysis, a clear zone $\beta$ hemolysis, and no change $\mathrm{\gamma}$-hemolysis (i.e., no hemolysis) (Jeon et al., 2018).

\section{SCREENING OF AMYLASE PRODUCING BACTERIA}

Bacterial strain was screened for amylolytic properties by starch hydrolysis test, on starch $(1 \%, 2 \%, 3 \% \mathrm{w} / \mathrm{v})$ agar plate. The culture medium was sterilized by autoclaving at $121{ }^{\circ} \mathrm{C}$, for $15 \mathrm{~min}$. The strain was streaked on the starch agar plate, followed by incubated at $37{ }^{\circ} \mathrm{C}$, for $24 \mathrm{~h}$. After incubation, $1 \%$ iodine solution (Lugol solution from Gram's staining) was flooded on the starch agar plate. A clear zone of hydrolysis on starch (after addition of iodine), around bacterial growth, is an indication of amylase production (Singh et al., 2015).

\section{SCREENING OF PROTEASE PRODUCING BACTERIA}

Bacillus subtilis ATCC 6051a was screened for proteolytic activity. The bacteria strain was inoculated on the agar plates containing casein $(1 \% \mathrm{w} / \mathrm{v})$ and milk powder $(1 \% \mathrm{w} / \mathrm{v})$, incubated at $37^{\circ} \mathrm{C}$, for $48 \mathrm{~h}$. The plates were flooded with $25 \%$ TCA (trichloroacetic acid) solution and incubated for 15 min., at $45{ }^{\circ} \mathrm{C}$ (Siddalingeshwara et al., 2010). Protease synthesis was observed by a zone of clearance on agar plate.

\section{RESULTS AND DISCUSSION}

\section{Morphological and biochemical characterization}

Colony morphology was determined on nutrient agar after $24 \mathrm{~h}$ incubation at $30^{\circ} \mathrm{C}$, under aerobic conditions. Grown colonies were opaque, whitish with rough matte surface, irregular edged and diameter 1.2-5 $\mathrm{mm}$ (Figure 1).

After growth in the nutrient medium, the tested strain at microscopic observation appeared as Gram positive rods shaped, arranged in diploid form, in short chains or in small irregular pairs (Figure 2).

Bacillus subtilis ATCC 6051a produced oval endospores located central, paracentral or subterminal positions without distorting the vegetative cell.
Bacilli present the ability of sporulation, making them stabile to survive at low $\mathrm{pH}$ of gastrointestinal tract (GIT) and during thermal processing and storage of feed (Elshaghabee et al., 2017). This statement is reinforced by Merchant et al. (2011) which affirmed that Bacillus spp. can be used as DFM in animal nutrition because the $\mathrm{pH}$ in the small intestine is 6 to 7 , which is optimal for spores to germinate, grow and produce enzymes and, also, to resist of the enzymatic degradation and stomach's acidic condition.

The strain was catalase positive, formed gas bubbles after addition of $3 \%$ solution $\mathrm{H}_{2} \mathrm{O}_{2}$. Hosoi et al. (2000) reported that $B$. subtilis can stimulate the growth and viability of Lactobacillus spp., maybe through the production of catalase. In addition, the spores resistant of $B$. subtilis to acid and oxygen may influence the intestinal microbiota and affect the microbial community from piglet feces. These data show the strong interaction between the $B$. subtilis and Lactobacillus.

Results obtained from the API $50 \mathrm{CHB}$ tests indicated that used test was able to confirm tested strain B. subtilis ATCC 6051a around $99.4 \%$ ID (very good percentage identification) and ABIS online ( $90.7 \%$ similarity). The fermentation capacity of carbohydrate was observed by the discoloration of the basal medium, from red to yellow, as positive answer (Figure 3 ).

The results by API $50 \mathrm{CHB}$ were registered as final interpretation after $48 \mathrm{~h}$, at $37^{\circ} \mathrm{C}$ (Table 1).

B. subtilis ATCC 6051a fermented D-glycerol, salicin, D-cellobiose, D-maltose, Larabinose, D-ribose, D-melibiose, D-xylose, D-saccharose (sucrose), D-trehalose, Draffinose, D-glucose, starch, D-fructose, glycogen, D-mannose, gentibiose, Dturanose, inositol, D-mannitol, D-sorbitol, methyl-aD-glucopyranoside, amygdalin, arbutin and esculin.

The strain did not ferment of D-arabinose, D-lactose, L-xylose, D-adonitol, methyl- $\beta D$ xylopyranoside, D-melezitose, D-galactose, xylitol, L-sorbose, L-rhamnose, dulcitol, Dlyxose, D-tagatose, D-fucose, L-fucose, methyl-aD-mannopyranoside, D-arabitol, L- 
arabitol, $\mathrm{N}$-acetylglucosamine, potassium gluconate, potassium 2-ketogluconate and potassium 5-ketogluconate.

After incubation, the change in colour of API $50 \mathrm{CHB}$ medium from red to yellow, represents a positive result corresponds to the substrates acidification (Aruwa and Olatope,

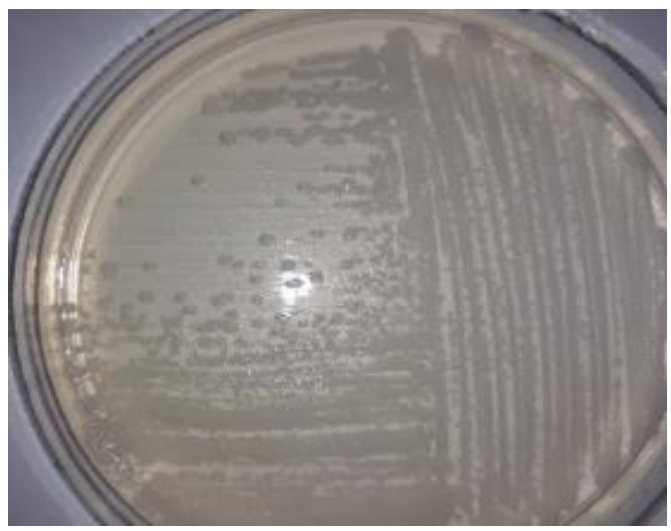

Figure 1. Cultural aspect on agar plate for Bacillus subtilis ATCC 6051a

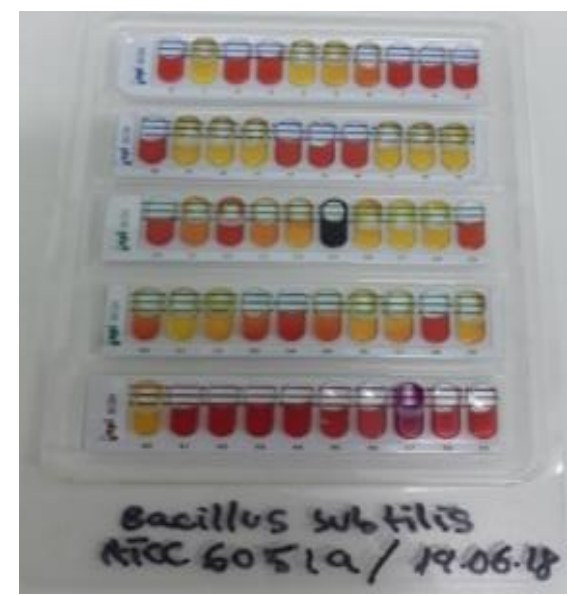

Figure 3. API $50 \mathrm{CHB}$ strips inoculated with Bacillus subtilis ATCC $6051 a$
2015).

\section{Hemolysis production}

The hemolytic evaluation was assayed on Trypticase soy agar supplemented with $5 \%$ sheep blood (TSA, Sanimed) and it is based on the ability of strain to lyse blood cells of culture medium.

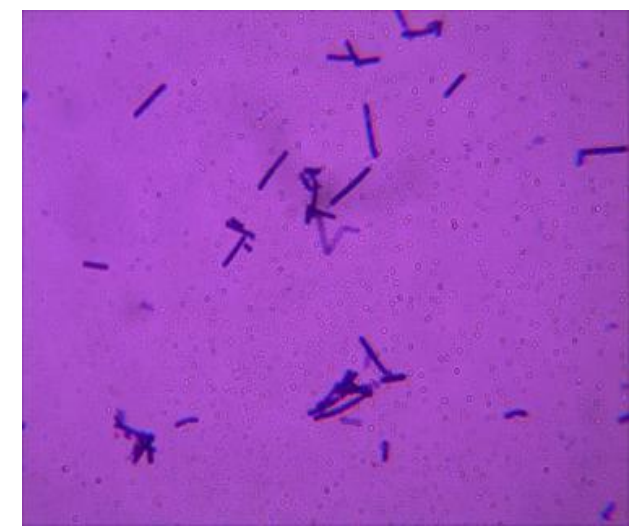

Figure 2. Microscopic observation of Bacillus subtilis ATCC 6051a strain (1000x)

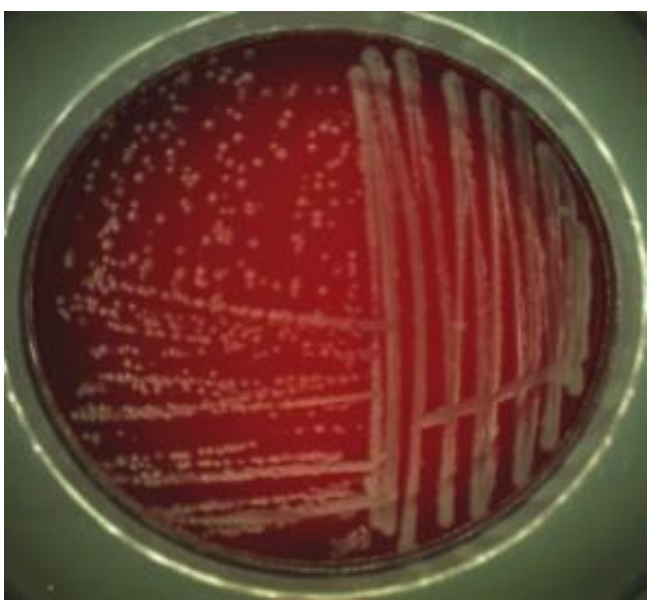

Figure 4. Haemolysis assay of Bacillus subtilis $6051 a$, at $37^{\circ} \mathrm{C}, 24 \mathrm{~h}$

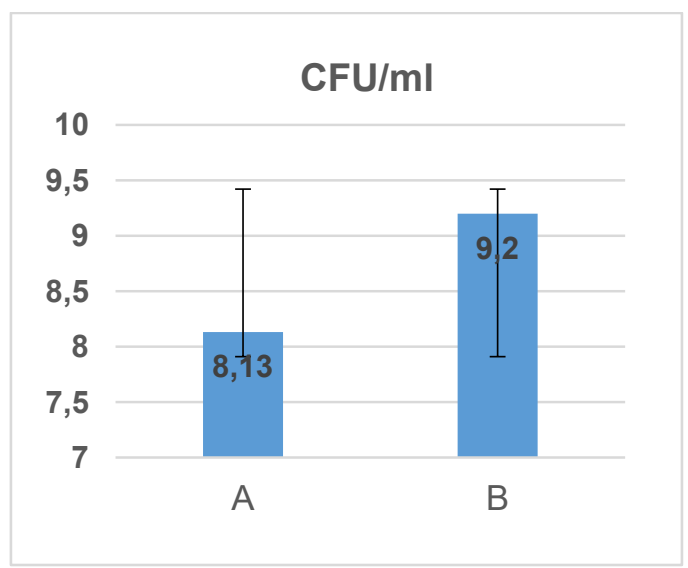

Figure 5. Bacterial growth (A: static incubation; B: shaking incubation) 
Table 1.

The results obtained with API $50 \mathrm{CHB}$ for B. subtillis ATCC 6051a

\begin{tabular}{llll}
\hline Glycerol & + & Salicin & + \\
Erythritol & - & D-cellobiose & + \\
D-arabinose & - & D-maltose & + \\
L-arabinose & + & D-lactose & - \\
D-ribose & + & D-melibiose & + \\
D-xylose & + & D-saccharose (sucrose) & + \\
L-xylose & - & D-trehalose & + \\
D-adonitol & - & Inulin & $+/ ?$ \\
Methyl- $\beta$ D-xylopyranoside & - & D-melezitose & - \\
D-galactose & - & D-raffinose & + \\
D-glucose & + & Starch & + \\
D-fructose & + & Glycogen & + \\
D-mannose & + & Xylitol & - \\
L-sorbose & - & Gentibiose & + \\
L-rhamnose & - & D-turanose & + \\
Dulcitol & - & D-lyxose & - \\
Inositol & + & D-tagatose & - \\
D-mannitol & + & D-fucose & - \\
D-sorbitol & + & L-fucose & - \\
Methyl-aD-mannopyranoside & - & D-arabitol & - \\
Methyl-aD-glucopyranoside & + & L-arabitol & - \\
N-acetylglucosamine & - & Potassium gluconate & - \\
Amygdalin & + & Potassium 2-ketogluconate & - \\
Arbutin & + & Potassium 5-ketogluconate & - \\
Esculin & + & &
\end{tabular}

The safety of $B$. subtilis ATCC 6051a to be used as a potential probiotic in piglets' nutrition was confirmed by non-hemolytic activity on $5 \%$ sheep blood agar plate $(\gamma-$ hemolysis) (Figure 4). Similar observation for Bacillus spp. was reported by Sorokulova et al. (2008).

Non-hemolytic activity is one of the main criteria needed to be satisfied by a probiotic organism which confirms its non-pathogenicity (Jung and Chang, 2012).

Bacillus strains are known as potential probiotics which could promote animals' health by direct consumption of high concentrations of viable number of cells (Guo et al., 2006; Abdhul et al., 2015). For a strain to be selected as a possible probiotic, it should not form halo of degradation around the developed colony.

It can be noticed that, if a strain involved a clear zone around colonies on blood sheep agar that indicate a complete hydrolysis $(\beta-$ hemolysis), the strain must be eliminated to be used as a probiotic in animal nutrition. Non-hemolysis ( $\gamma$-hemolysis) and a hemolysis (a green zone around colony) are considered to be safe (Seker, 2010).

\section{Growth of the bacterial strain}

The growth of $B$. subtilis was monitored after $24 \mathrm{~h}$ incubation at $30{ }^{\circ} \mathrm{C}$ under static conditions and under a constant agitation (150 rpm). After static incubation number cells of $B$. subtilis were amounted $1.36 \times 10^{8}$ $(\mathrm{CFU} / \mathrm{ml})$, while it is in case of agitation were amounted $1.6 \times 10^{9}(\mathrm{CFU} / \mathrm{ml})$. The experimental results, given in Figure 5 , showed that agitation is a better parameter for growing bacteria, compared with the static incubation. The result was expressed as logarithm of colony forming units $/ \mathrm{ml}$.

\section{Screening of amylase enzyme}

Productivity of the amylase, as qualitative assay, was investigated on starch agar plate $(1-3 \% \mathrm{w} / \mathrm{v}$ starch). Production of this enzyme was studied after $24 \mathrm{~h}$ of incubation at $30{ }^{\circ} \mathrm{C}$ and $\mathrm{pH}$ 7. A clear zone of starch hydrolysis, surrounding bacterial growth, represents the capacity of tested strain to synthesize enzyme amylase (Figure 6). According to Singh et al. (2015), the Bacillus spp. is a group with strong properties to produces amylase. In their study, Mishra and Behera (2018) presented similar data of amylase hydrolysis on starch agar plate with a clear zone around Bacillus spp. 
This qualitative method for evaluation of amylase production by $B$. subtilis ATCC 6051 a strain provides information about the substrate on which it acts and is used for selection of the right diet for animals.
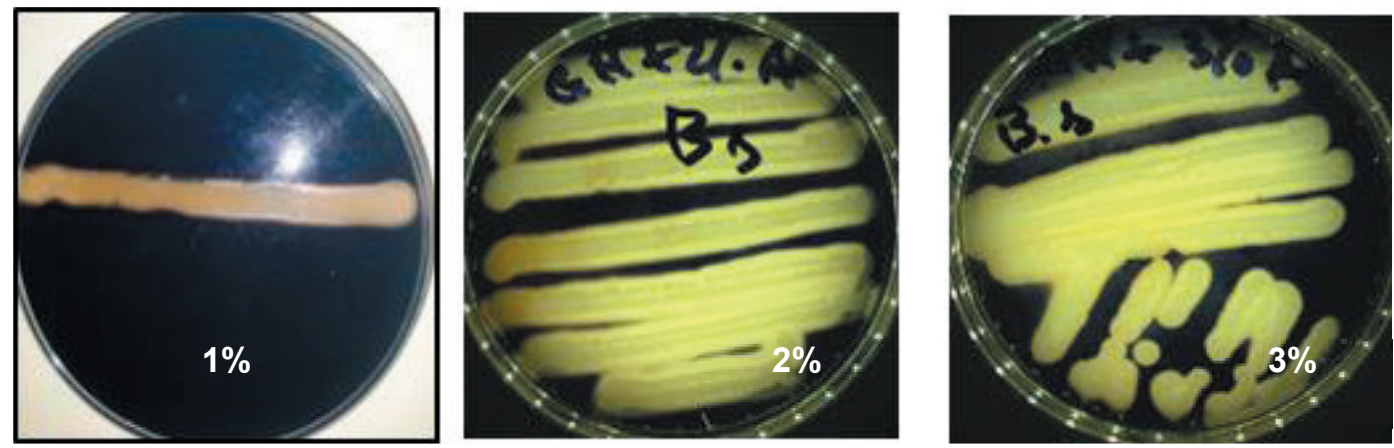

Figure 6. Screening of hydrolysis amylase of Bacillus subtilis ATCC 6051a
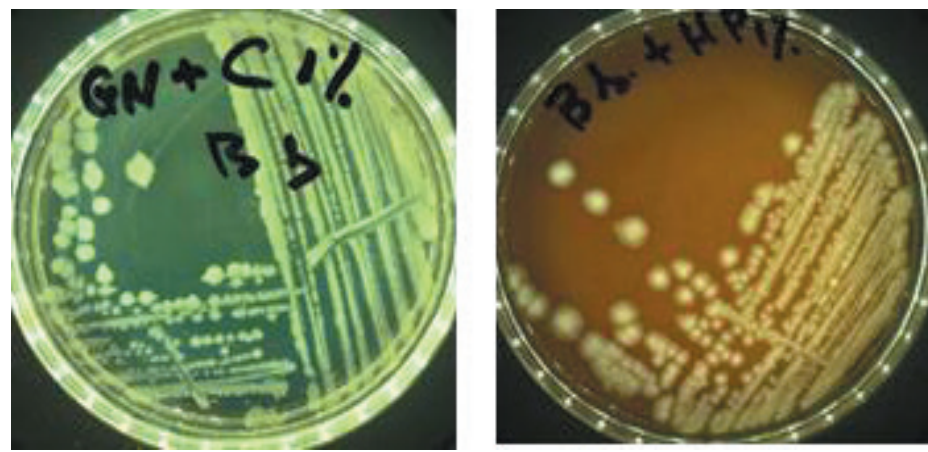

Figure 7. Screening of hydrolysis protease of Bacillus subtilis ATCC 6051a

Generally, Bacillus spp. are sources of extracellular hydrolytic enzymes, which may help the digestive process and utilization of nutrients from feed (Davis et al., 2008). Weaning is a difficult period for piglets due to their incomplete development of the enzymatic system (Habeanu et al., 2017). The change from highly digestible liquid milk from sows to a less-digestible, more complex solid feed has also critical consequences on piglet performance and the physiology of their GIT (Campbell et al., 2013).

Feeding exogenous microbial enzymes could aid digestion of complex matrix of non-milk-based ingredients present in the piglet's weaning diet and could bridge the gap until the piglet's endogenous enzyme secretory capacity for a-amylase and proteases has had time to develop. Dietary supplementation with Bacillus spp. has been reported to improve growth performance, immune status, intestinal microbiota and nutrient digestibility of non-starch poly- saccharides (NSP) from corndiets piglets (Lei and Kim, 2014), due to exogenous enzymes secreted into the host intestine or to endogenous enzymes available into the bacterial cells and released when they are lysed by the effect of the acidic environment of hosts' stomach (Ortiz et al., 2015).

\section{Screening of protease enzyme}

Protease and amylase production was identified on the nutrient agar supplemented with starch and milk powder, by observing the zone of hydrolysis around the colony or growth (Nagaraju and Divakar, 2012).

The cleared zone around colony on the agar plate medium represents the enzymatic potential of $B$. subtilis ATCC 6051a (Figure 7). Lee et al. (2012) reported that addition of extracellular microbial enzymes with probiotic properties can enhance feed digestibility, for example the exogenous proteases in feed can be an option to reduce dietary protein levels maintaining high animal performance. 


\section{CONCLUSIONS}

The results suggested that the Bacillus subtilis ATCC 6051a strain presents the capacity to secret amylase and protease enzymes. The strain showed no hemolytic activity ( $\mathrm{\gamma}$ - hemolysis) on TSA medium confirming that it is not pathogenic. Further experiments will be performed to study other probiotic features such as: resistance to $\mathrm{pH} 2.0$, resistance to bile acids and salts, antibacterial activity, induction of local immune response etc. Bacillus subtilis ATCC 6051a represents a source of amylase and protease and their probiotic potential will be researched in animal nutrition as a source of feed additive.

\section{ACKNOWLEDGEMENTS}

This study was funded by Romanian Ministry of Research and Innovation through Program 1 - Development National Research-Development, Sub-program 1.2 Institutional Performance - Projects funding excellence in $R$ \& $D$, Contract no. 17 PFE/ 17.10.2018 and Grant PN 18200103.

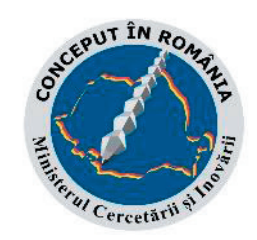

\section{REFERENCES}

1. Abdhul, K., Ganesh, M., Shanmughapriya, S., Vanithamani, S., Kanagavel, M., Anbarasu, K., Natarajaseenivasan, K. (2015). Bacteriocinogenic potential of a probiotic strain Bacillus coagulans [BDU3] from Ngari. International Journal of Biological Macromolecules, 79, 800-806.

2. Aruwa, C.E., Olatope, O.A. (2015). Characterization of Bacillus species from convenience foods with conventional and API Kit Method: A comparative analysis. Journal of Applied Life Sciences International, 3 (1), 42-48.

3. FAO 2016. Probiotics in animal nutrition Production, impact and regulation. By Bajagai, Y.S., Klieve, A.V., Dart, P.J., Bryden, W.L. Ed. H.P.S. Makkar. FAO Animal Production and Health Paper, 179, Rome, Italy. (http://www.fao.org/3/a-i5933e.pdf).

4. Campbell, J.M., Crenshaw, J.D., Polo, J. (2013). The biological stress of early weaned piglets. Journal of Animal Science and Biotechnology, 4 (19), 1-4.

5. Cutting, S.M. (2011). Bacillus probiotics. Food Microbiology, 28, 214-220.
6. Davis, M.E., Parrott, T., Brown, D.C., De Rodas, B.Z., Johnson, Z.B., Maxwell, C.V., Rehberger, T. (2008). Effect of a Bacillus-based direct fed microbial feed supplement on growth performance and pen cleaning characteristics of growing finishing pigs. Journal of Animal Science, 88, 3320-3326.

7. Dumitru, M., Sorescu, I., Jurcoane, S., Câmpeanu, G., Tabuc, C., Hăbeanu, M. (2017). Assessing of morphological, cultural, biochemical profile and enzymatic activity of a Lactobacillus paracasei CCM 1837 strain. Academy of Romanian Scientists Annals, Series on Biological Sciences, 6 (2), 22-31.

8. Elshaghabee, F.M.F., Rokana, N., Gulhane, R.D., Sharma, C., Panwar, H. (2017). Bacillus as potential probiotics: Status, concerns, and future perspectives. Frontiers in Microbiology, 8 (1490), $1-15$.

9. FAO/WHO (2001). Health and nutritional properties of probiotics in food including powder milk with live lactic acid bacteria. Report of a Joint FAOMHO Expert Consultation on Evaluation of Health and Nutritional Properties of Probiotics in Food including Powder Milk with Live Lactic Acid Bacteria. In Probiotics in food-Health and nutritional properties and guidelines for evaluation. FAO Food and Nutrition Paper, 85, 2006, WHO, FAO. (http://www.fao.org/3/a-a0512e.pdf).

10. Guo, X., Li, D., Lu W., Piao, X., Chen, X. (2006). Screening of Bacillus strains as potential probiotics and subsequent confirmation of the in vivo effectiveness of Bacillus subtilis MA139 in pigs. Antonie van Leeuwenhoek, 90 (2), 139-146.

11. Habeanu, M., Lefter, N., Gheorghe, A., Tabuc, C., Dumitru, M., Ciurescu, G., Palade, M. (2017). Effects of dietary peas mixed with linseed $(3: 1)$ on the growth performance, enteritis and certain serum parameter in weaned piglets. Food and Feed Research, 44 (2), 173-180.

12. Hosoi, T., Ametani, A., Kiuchi, K., Kaminogawa, S. (2000). Improved growth and viability of lactobacilli in the presence of Bacillus subtilis (natto), catalase or subtilisin. Canadian Journal of Microbiology, 46, 892-897.

13. Jeon, H.L., Yang, S.J., Son, S.H., Kim, W.S., Lee, N.K., Paik, H.D. (2018). Evaluation of probiotic Bacillus subtilis P229 isolated from cheonggukjang and its application in soybean fermentation. Food Science and Technology, 97, 94-99.

14. Jung, J.H., Chang, H.C. (2012). Evaluation of the probiotic potential of Bacillus polyfermenticus CJ6 isolated from meju, a Korean soybean fermentation starter. Journal of Microbiology and Biotechnology, 22, 1510-1517.

15. Kaewtapee, C., Burbach, K., Tomforde, G., Hartinger, T., Silva, A.C., Heinritz, S., Seifert, J., Wiltafsky, M., Mosenthin, R.F., Rosenfelder-Kuon, P. (2017). Effect of Bacillus subtilis and Bacillus licheniformis supplementation in diets with lowand high-protein content on ileal crude protein and amino acid digestibility and intestinal micro- 
biota composition of growing pigs. Journal of Animal Science and Biotechnology, 8 (37), 1-15.

16. Lee, J., Park, I., Choi, Y., Cho, J. (2012). Bacillus strains as feed additives: In vitro evaluation of its potential probiotic properties. Revista Colombiana de Ciencias Pecuarias, 25, 577-585.

17. Lei, Y., Kim, I.H. (2014). Effect of Phaffia rhodozyma on performance, nutrient digestibility, blood characteristics, and meat quality in finishing pigs. Journal of Animal Science, 92, 171-176.

18. Lese, T.D., Knarreborg, A., Worm, J. (2007). Germination and outgrowth of Bacillus subtilis and Bacillus licheniformis spores in the gastrointestinal tract of pigs. Journal of Applied Microbiology, 104, 1025-1033.

19. Link, R., Kovac, G. (2006). The efect of probiotic Bioplus 2B on feed efficiency and metabolic parameters in swine. Biologia, Bratislava, Section Cellular and Molecular Biology, 61 (6), 783-787.

20. Maneewan, C., Yamauchi, K., Thirabunyanon, M., Siri, S., Mekbungwan, A., Thongwittaya, N. (2011). Development of Bacillus subtilis MP and effective utilization on productivity and microorganisms in feces of suckling piglets. The International Journal of Applied Research in Veterinary Medicine, 9 (4), 382-387.

21. Markowiak, P., Śliżewska, K. (2018). The role of probiotics, prebiotics and synbiotics in animal nutrition. Gut Pathogens, 20 (21), 1-20.

22. Meng, Q.W., Yan, L., Ao, X., Zhou, T.X., Wang, J.P., Lee, J.H., Kim, H. (2010). Influence of probiotics in different energy and nutrient density diets on growth performance, nutrient digestibility, meat quality, and blood characteristics in growing-finishing pigs. Journal of Animal Science, 88, 3320-3326.

23. Merchant, H.A., McConnell, E.L., Liu, F., Ramaswamy, C., Kulkarni, R.P., Basit, A.W., Murdan, S. (2011). Assessment of gastrointestinal $\mathrm{pH}$, fluid and lymphoid tissue in the Guinea pig, rabbit and pig and implications for their use in drug development. European Journal of Pharmaceutical Science, 42, 3-10.

24. Mishra, S., Behera, N. (2018). Amylase activity of a starch degrading bacteria isolated from soil receiving kitchen wastes. African Journal of Biotechnology, 7 (18), 3326-3331.

25. Ortiz, A.C.S., González, A.L., Campa-Córdova, A.I., Montes, R.E., María del Carmen, F.M., Mazón-Suástegui, J.M.M. (2015). Isolation and characterization of potential probiotic bacteria from pustulose ark (Anadara tuberculosa) suitable for shrimp farming. Latin American Journal of Aquatic Research, 43 (1), 123-136.

26. Breed, R.S., Murray, E.G.D., Smith, N.R. (1957). Bergey's Manual of Systematic Bacteriology, Seventh Edition, Williams and Wilkins, Baltimore, Md, USA.

27. Ritter, A.C., Folmer Correa, A.P., Veras, F.F., Brandelli, A., (2018). Characterization of Bacillus subtilis available as probiotics. Journal of Microbiology Research, 8 (2), 23-32.

28. Seker E. (2010). Identification of Candida species isolated from bovine mastitic milk and their in vitro hemolytic activity in Western Turkey. Mycopathologia, 169, 303 - 308.

29. Siddalingeshwara, K.G., Huchesh, C.H., Puttaraju, H.P., Karthic, J., Sudipta, K.M., Pramod, T., Vishwanatha, T. (2010). Screening and characterization of protease from Bacillus sp. International Journal of Applied Biology and Pharmaceutical Technology, 1 (2), 575-581.

30. Singh, V., Sharma, R., Sharma, P. (2015). Isolation, screening and optimization of amylase producing Bacillus $s p$. from soil. Asian Pacific Journal of Health Science, 2 (3), 86-93.

31. Sorokulova, I.B., Pinchuk, I.V., Denayrolles, M., Osipova, I.G., Huang, J.M., Cutting, S.M., Urdaci, M.C. (2008). The safety of two Bacillus probiotic strains for human use. Digestive Diseases and Science, 53 (4), 954-963.

32. Stoica, C., Sorescu I. (2017). ABIS online Advanced Bacterial Identification Software, an original tool for phenotypic bacterial identification. Regnum Prokaryotae (www.tgw1916.net).

33. Nagaraju, E.V., Divakar, G. (2012). Screening and characterization of protease producing $\mathrm{Ba}$ cillus spp. from spoiled vegetables and fruits. International Journal of Advances in Pharmacy, Biology and Chemistry, 1 (4), 485-488.

34. Vishwanatha, T., Spoorthi, N.J., Reena, V., Divyashree, B.C., Siddalingeshwara, K.G., Karthic, J., Sudipta, K.M. (2010). Screening of substrates for protease production from Bacillus licheniformis. International Journal of Engineering Science and Technology, 2 (11), 6550-6554.

35. Yang, F., Hou, C., Zeng, X., Wqiao, S. (2015). The use of lactic acid bacteria as a probiotic in swine diets. Pathogens, 4, 34-45.

36. Yirga, H. (2015). The use of probiotics in animal nutrition. Journal of Probiotic Health, 3, 1-10.

37. Zaid, A.A. (2018). Study the effect of probiotic bacteria isolated from foods on pathogens. Biomedical Research, 29 (12), 2509-2515. 


\title{
ПРЕЛИМИНАРНА КАРАКТЕРИЗАЦИЈА ВРСТЕ ВАCILLUS SUBTILIS KAO ПРОБИОТИЧКОГ ДОДАТКА ИСХРАНИ ПРАСАДИ
}

\author{
Михаела Думитру ${ }^{* 1,2}$, Ионут Сореску ${ }^{1}$, Михаела Хабеану ${ }^{1}$, Кристина Табук ${ }^{1}$, Лавиниа \\ Идрицеану ${ }^{1}$, Стефрана Јуркоане ${ }^{2,3}$ \\ ${ }^{1}$ Национални истраживачки развојни институт за биологију и исхрану животиња (ИБНА), \\ Букурешт бр. 1, Балотешти, 077015, Румунија \\ ${ }^{2}$ Универзитет пољопривредних наука и ветеринарске медицине из Букурешта, 59, \\ Марасти булевар, Букурешт, Румунија \\ ${ }^{3}$ Румунска академија наука, Букурешт, Румунија
}

Сажетак: Циљ овог истраживања био је карактеризација бактеријске врсте Bacillus subtilis ATCC 6051а, како би се утврдила могућност њене пробиотичке примене у исхрани прасади. У овом истраживању анализиране су морфолошке, културалне и биохемијске карактеристике тест соја, као и његова хемолитичка и ензимска активност (амилаза и протеаза). Идентификација и анализа биохемијских карактеристика тест соја је спроведена применом каталаза теста, API идентификациониог система (API 50 CHB Biomerieux) и примену apiveb API 50 CHB V 4.0 coфртвера (B. subtilis, врло висок ниво идентификације, 99,4\% ID) уз ABIS online подршку. Хемолитичка активност тест соја је спроведена на крвном агару. Способност раста тест соја је испитана у статичким условима $\left(30{ }^{\circ} \mathrm{C}, 24 \mathrm{~h}, 1.36\right.$ x $\left.10^{8} \mathrm{CFU} / \mathrm{ml}\right)$ и условима константне агитације $\left(30^{\circ} \mathrm{C}, 24 \mathrm{~h}, 150 \mathrm{rpm},\left(1,6 \mathrm{k} 10^{9} \mathrm{CFU} / \mathrm{ml}\right)\right.$. Резултати су показали да је тест сој Грам-позитивна штапићаста бактерија, са штапићима распоређеним у виду кратких ланаца или неправилним паровима са способношћу формирања спора на хранљивом медијуму. Ендоспоре су локализоване парацентрално и суптерминално не узрокујући деформацију вегетативне ћелије. Тестирани сој расте аеробно и не показује хемолитичку активност. Ензимска активност тестираног соја је утврђивана као појава просветљених зона око саме бактеријске колоније. На основу добијених резултата може се закључити да испитивани сој има пробиотичке особине и може се надаље користити за испитивање других пробиотичких особина (отпорност при рН 2.0, отпорност на жучне киселине и соли, антибактеријска активност, индукција локалног имунолошког одговора итд.).

Кључне речи: API 50 CHB, хемолитичка активност, ензиматски скрининट

Received: 29 October 2018

Received in revised form: 12 December 2018

Accepted: 19 December 2018 